\author{
Асауленко Н.В. \\ аспірант \\ кафедра менеджменту та логістики \\ Одеська національна академія харчових технологій \\ вул. Канатна, 112, м. Одеса, Україна, 65039 \\ E-mail: Nataliya.asaulenko@ukr.net \\ ORCID: 0000-0001-7057-4614
}

\title{
ОСОБЛИВОСТІ ІННОВАЦІЙНОГО ПРОЦЕСУ НА ПІДПРИЄМСТВАХ ІНДУСТРІЇ ГОСТИННОСТІ
}

В статті проведений аналіз поняття інноваційного процесу та інновацій, з'ясовано їхню сутність, починаючи від перших згадувань у науковій літературі. Зображена проблематика інновацій в економічній теорії та практиці управління підприємствами. Представлено особливості інновацій в процесі реалізації на підприємствах саме індустрії гостинності як одного з найперспективніших напрямів розвитку економіки країни. Виділено головну їхню особливість - сервісний характер. Зазначено важливість і доцільність поділу інновацій на сервісні та виробничі. Показано, що поняття «сервісні інновації» означає інновації сфери послуг. Виявлено, що науковці щодо поглядів на інноваційні особливості сфери послуг поділяються на дві групи: які не розмежовують сервісні і виробничі інновації та абсолютно відрізняють їх. Саме прихильники розмежувального підходу формують специфічний характер сервісних інновацій. Це дозволило виділити особливості сервісних інновацій, які застосовуються підприємствами індустрії гостинності. На основі проведеного дослідження запропоновано напрями розвитку інновацій підприємствами індустрії гостинності.

Ключові слова: індустрія гостинности, інновація, інноваційна діяльність, інноваційний процес, сервісні інновації, підприємства індустрії гостинності.

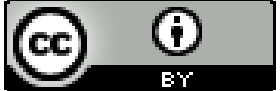

This work is licensed under a Creative Commons Attribution 4.0 International License http://creativecommons.org/licenses/by/4.0/
Постановка проблеми та її зв'язок з важливими науковими та практичними завданнями. Останнім часом особливого значення набуває наукова дискусія щодо важливості інновацій для розвитку і вдосконалення підприємств. Не є винятком і підприємства, що відносяться до індустрії гостинності. Вивчення цієї проблематики є особливо актуальним 3 огляду на відносну новизну даного поняття для вітчизняної практики, а також наявного у нашої країни потенціалу для розвитку цієї індустрії. Не дивно, що вчені поступово починають обирати індустрію гостинності як об'єкт своїх досліджень. Однак, на нашу думку, методологічні аспекти дослідження індустрії гостинності не до кінця сформовані: зокрема, не склалося чіткого розуміння відмінних характеристик інноваційних процесів на підприємствах індустрії гостинності. Невирішеність цих проблем значно ускладнює подальше дослідження, зокрема вивчення питань інноваційної діяльності на підприємствах індустрії гостинності.

Аналіз останніх публікацій по проблемі. Інноваційний підхід займає важливе місце в наукових прадях відомих дослідників. Так, проблеми понятійного апарату і теоретичні питання інноваційної діяльності представлені в роботах П. Друкера, В. Г. Мединського, В. І. Орєхова, М. Портера, М. Тодаро, Й. Шумпетера та ін. Незважаючи на те, що в останні роки в вітчизняній науці з'явилося досить багато серйозних і різнобічних досліджень 3 проблем інновацій, вони, в основному, зачіпають сферу матеріального виробництва. При цьому різні аспекти управління готельним бізнесом розглядаються в роботах: Ю. А. Александрової, В. Г. Гуляєва, М. А. Морозової, С. Свистунова, Н. Б. Щеніковой та ін. Специфічний характер управління інноваційною діяльністю, в т. ч. на підприємствах індустрії гостинності розкривається в дослідницьких матеріалах: І. С. Безрукова, В. Г. Зінова, Н. О. Коваленко, О. О. Пахомчикової, М. М. Поташника, Л. В. Сакун та ін. В цілому, в роботах перерахованих вище авторів закладена теоретична база управління інноваційною діяльністю, в тому числі на підприємствах індустрії гостинності. Проте, в існуючих підходах до використання інновацій в індустрії гостинності відсутня чітка систематизація особливостей інноваційного процесу на цих підприємствах.

Формулювання цілей дослідження. Актуальність обраної теми обумовлена тим, що аналіз робіт зарубіжних і вітчизняних вчених дозволяє виявити значні відмінності, наявні як в понятійному апараті, так і в основних показниках оцінки інноваційних процесів. Таким чином, метою статті є дослідження сучасних особливостей інноваційного процесу на підприємствах індустрії гостинності. Досягнення поставленої мети передбачає передусім вирішення 
наступних задач: виявлення сутністного значення таких понять, як інноваційний процес та інновації; 3'ясування сутності поняття «сервісні інновації» та їхні особливості для підприємств індустрії гостинності; виділення основних напрямів розвитку інновацій підприємствами індустрії гостинності. Саме вирішення поставлених задач дасть можливість з'ясувати особливості інноваційного процесу на підприємствах індустрії гостинності.

Виклад основних результатів та їх обгрунтування. В часи інтенсивного розвитку наукової революції саме інновації $є$ важливою рушійною силою для процесів у суспільному виробництві. Використання термінів інновацій, нововведення, новацій, інноваційний процес, інноваційна діяльність, інвестиції та багато інших міцно увійшли в повсякденне життя і діяльність підприємств, підприємців, технологів, керівників та інших працівників галузей і сфер національної економіки. Важливо, що в теорії і практиці управління підприємствами досі не вироблено єдиного, загальноприйнятого підходу до використання основних понять інноваційного менеджменту. Однак, у науковій літературі, присвяченій вивченню проблем інноватики, простежуються різні погляди на сутність і зміст інновації, інноваційних процесів й інноваційної діяльності. Перший найбільш повний опис понять, категорій та інноваційних процесів ввів в науку австрійський вчений Йозеф Шумпетер. В ті часи ще застосовували поняття інновації, а мова йшла про «нові комбінації», «кращі способи», «використання», «вплив» змін на розвиток.

Сьогодні під «використанням» мається на увазі цілий ряд різних способів застосування благ та різноманітні види поведінки щодо речей, а під «впливом» - будь-якого роду просторові зміни, механічні, хімічні та інші процеси. 3 технічної або економічної точки зору виробляти означає комбінувати наявні в нашому розпорядженні речі і сили. Кожен метод виробництва означає певну комбінацію. Різні методи виробництва можуть відрізнятися за характером i способом, яким вони утворюють комбінацію, тобто або за об'єктами комбінування, або за співвідношенням їхньої кількості. Кожен конкретний акт виробництва є для нас подібною комбінацією [1, с. 72].

Цікаво, що аспекти нових змін у розвитку, які розглядав Й. Шумпетер і представив інноваційний процес, виділивши типові їхні зміни щодо: робництва;

- нової техніки, процесів чи забезпечення ви-

- запуску товарів із новими властивостями;

- споживання нових видів сировини;

- зміни організації та забезпечення процесу виробництва;

- створення нових збутових ринків.

Важливо, що вже М. Портер при обгрунтуванні теорії конкурентної переваги зосереджує увагу на наступному визначення нововведення: господарюючий суб'єкт виборює свою перевагу серед конкурентів, коли знаходить новітні способи ведення конкурентної боротьби, що називається «нововведенням». В найширшому сенсі до нововведення включа- ється вдосконалення технологій, а також методів та способів організації діяльності. Саме оновлення спроможне виражатися в змінюванні товарів чи виробничих процесів, новітніх підходах до маркетингової діяльності та інших напрямах поширення товарів, послуг. Такі новатори примушують реалізовувати швидше подібні зміни [2].

На особливу увагу, на наш погляд, заслуговує, думка М. Портер про те, що значна частка змін має «еволюційний, а не радикальний характер», при цьому досить часто накопичення незначних змін приносить більше, ніж «великий технологічний прорив» [2, c. 64].

Проблематика інновацій майже три десятиліття залишалася осторонь від основного потоку економічної теорії та іiі застосування в практиці управління підприємствами. У 60-і роки ХХ ст., в період прискореного науково-технічного розвитку, ситуація змінилася. Такий стан справ став можливим завдяки здобуткам Джеймса Брайта, який звернув увагу на книги Шумпетера і його послідовників і довів, що саме науково-технічне нововведення є єдиним процесом, що складається із поєднання науки, техніки, економіки, підприємництва і управління. Іншими словами, таким процесом можна вважати «трансформування наукового знання в фізичну реальність, що змінює суспільство» [3]. Він зазначив про необхідність уникати підходу, який базується на ідеї простого оновлення продукції. Такий підхід обмежує пошук шляхів, що пояснюють як саме застосувати нову техніку і не завжди має максимальний комерційний потенціал.

Б. Твисс підкреслює, що нововведення є застосуванням (процесом), під час якого винахід або ідея знаходить конкретний економічний сенс, тобто «винахід стає нововведенням», коли приносить позитивний результат на певному ринку. На його думку, проблема не лише у нововведення, а скоріше в результативному управлінні ними, що орієнтоване на прибуток [4]. При доведенні доцільності концептуального підходу щодо розуміння і вивчення інноваційного процесу Б. Твисс розглядає його як трансформаційний процес.

Цікаво, що за визначенням експертів Організації економічного співробітництва і розвитку (ОЕСР) науково-технічне нововведення - це «нове застосування науково-технічних знань, що приводить до успіху на ринку» [5].

Слід підкреслити, що нововведення є можливістю для успішного майбутнього в умовах сучасної ринкової економіки, але не є остаточною гарантією. На нашу думку, саме ринок дає економічну оцінку ідеї практичного використання нового знання і нововведення, визначає їхню подальшу долю - швидке впровадження або відсутність належної підтримки.

Як зазначає Б. Санто, інновація являє собою надзвичайно складний, невизначений за своїм результатом, насичений несподіваними ситуаціями на проміжних ділянках, важко прогнозований процес. Характеризує інновацію як виробничий фактор, який визначає формування продуктивності та валового національного продукту на тривалу перспективу. Його 
вагомий внесок зосереджений на обгрунтуванні концепції інноваційного ланцюга у вигляді лінійної послідовності певних етапів в процесі здійснення нововведень, різних моделей інноваційних процесів і моделювання інновацій.

Проте окрім дослідження інновацій як процесу управління, на наш погляд, доцільно відобразити їхні особливості в процесі реалізації на підприємствах саме індустрії гостинності як одного з найперспективніших напрямів розвитку економіки країни. Так, головною особливістю інновацій на підприємствах індустрії гостинності є їхній сервісний характер. Фахівці з інновацій виділили достатньо загальноприйнятих критеріальних ознак класифікації інновацій, приділивши особливу увагу їхньому поділу на сервісні та виробничі. Таке групування, саме $з$ методологічної точки зору, повинно мати першорядний характер.

Дійсно, під час аналізу вже існуючих інновацій, логічно прийти до висновку, що більша частина них орієнтована на фіксацію їхніх окремих видів на підприємствах матеріального виробництва. Для сервісних же підприємств багато 3 виділених критеріїв класифікації незастосовні, а іноді виявляють і зовсім протилежний характер. Так, Р. Баррас показав, що «продуктові інновації в сфері послуг мають «зворотний життєвий цикл»: він починається з використання нових технологій для підвищення ефективності виробництва, а завершується створенням зовсім нових послуг - на противагу циклу, характерному для суто матеріального виробництва, в якому спочатку створюються нові продукти поліпшеної якості (дизайну) і лише потім інноваційна активність зосереджується на підвищенні ефективності виробництва і здешевлення продукції» [6, с. 163].

До 90-х років вчені звертали недостатньо уваги на сервісні інновації в більшості секторів сфери послуг. Поняття «сервісних інновацій» пішло із зарубіжної літератури, де в якості сервісних позначаються інновації сфери послуг. У вітчизняній літературі цей термін не знайшов поширення, що, на думку автора, $є$ істотним упущенням. Вважаємо, що для ідентифікації інновацій, які були пов'язані з обслуговуючою діяльністю, слід використовувати термін «сервісні інновації». Так, за даними ресурсу Publish or Perish, у 19751989 рр. словосполучення «сервісні інновації» зустрічалося в заголовках всього восьми статей, а з 2010 по 2019 pp. - близько 5002. Безумовно, наведені дані носять відносний характер через те, що вони охоплюють лише англомовні публікації; до того ж існують дослідження, які в своїй назві не міститься терміну «сервісна інновація». Проте, вищеописана публікаційна тенденція досить показово висвітлює існуючу ситуацію із обізнаністю щодо них. На наш погляд, істотне поліпшення в характері вивчення сервісних інновацій було обумовлене підвищеним інтересом щодо дослідження сервісної індустрії як сектору економіки, який досить суттєво відрізняється від сфери матеріального виробництва [7].

Вагомий внесок щодо систематизації знань в сфері сервісних інновацій зробив Майлз Йен Дуглас. Вчений зазначає, що більша частина науковців в сфе- pi послуг щодо інноваційних особливостей поділяються на дві частини. Одна 3 них не розмежовує сервісні та виробничі інновації та дотримується думки, що доцільно застосувати у дослідженнях інноваційних процесів сфери надання послуг й виробництва товарів однакові підходи та методи. Інші схильні вважати, що процес надання послуг абсолютно відрізняється від виробництва товарів. Саме це й обумовлює застосування для оцінки спеціальних методів та інструментів щодо сервісних інновацій $[8$, с. 4].

Важливо підкреслити, що обидва підходи мають логічне обгрунтування. Прихильники першого (асиміляційного) підходу схиляються до думки про загальні риси товарів та послуг. Так, зауважують, що сфера послуг є таким само сектором економіки, як i інші, а різниця лише в тому, що їхня продукція носить більшою частиною нематеріальний характер, при цьому існуючі відмінності мають кількісний, а не якісний характер. Тобто концепції та теорії щодо сфери матеріального виробництва можна включати до інноваційної сфери послуг. Цього підходу дотримаються дослідники, чиї наукові пошуки від сфери матеріального виробництва поширились і на сферу послуг.

Прихильники другого (розмежувального) підходу схильні до думки, що і сфера послуг, і їі діяльність носять специфічний характер. Основним їхнім твердженням $є$ те, що дослідження сервісних інновацій потребує особливого інструментарію та нових теорій. Саме тому практика застосування інновацій підприємствами індустрії гостинності (яка належить безпосередньо до сфери послуг) виділяє наступні особливості сервісних інновацій:

1. Істотна більшість підприємств індустрії гостинності майже не займаються дослідженнями або розробками (НДДКР), саме тому реалізація сервісних інновацій, як правило, не вимагає вагомих фінансових вкладень.

2. Для підприємств індустрії гостинності менш характерним є використання радикально нових інновацій.

3. Підприємства індустрії гостинності в меншому ступені тяжіють до придбання основних фондів для здійснення інновацій, ніж підприємства сфери матеріального виробництва.

4. Підприємства індустрії гостинності, як правило, витрачають менше коштів на купівлю патентів і ліцензій, ніж підприємства матеріальної сфери.

5. На підприємствах індустрії гостинності менший відсоток доходів компаній спрямовується на здійснення інновацій.

6. Сервісні інновації є такими, які легко «копіювати» на власне підприємство індустрії гостинності.

7. Велике значення при здійсненні сервісних інновацій відводиться стратегії, а саме - стратегії управління людськими ресурсами. I як наслідок, брак кваліфікованих співробітників на підприємствах індустрії гостинності є головним бар'єром для здійснення успішної інноваційної діяльності. Для виробничих підприємств даний показник не є визначальним. 
8. Сервісні інновації мають більш широкий, проти виробничих, спектр напрямів розвитку. Якщо виробничі інновації спрямовані в основному на вдосконалення характеристик продукції, сервісні можуть поширюватися безпосередньо на послуги і процес взаємодії постачальника і споживача послуг.

9. Інтерактивна взаємодія постачальника i споживача має суттєвий вплив на сервісні інновації. Фактично вона може бути націлене на створення інновацій, які передбачають встановлення нових взаємозв'язків, відносин, каналів спільної діяльності. Розглянемо, наприклад, ведення систем самообслуговування і надання послуг в режимі онлайн, що обумволено сьогодні пандемією COVID-19 в світі. Вони сприяють навчанню і зміні поведінкових характеристик як виробника, так і споживача послуг [8, с. 8].

10. Відомо, що інновації діляться на продуктові (спрямовані на зміну або створення нових характеристик продукції) і процесні (спрямовані на вдосконалення технології виробництва). Зазначений поділ цілком закономірний в контексті його застосування для сфери матеріального виробництва. Для підприємств індустрії гостинності, навпаки, кордони між продуктовими та процесними інноваціями розмиті внаслідок залучення споживача в процес надання самої послуги (одночасності виробництва іiі й споживання).

11. Для підприємств індустрії гостинності велике значення має матеріальна «обстановка»: їхнє розташування, інтер'єр, дизайн приміщень, це потрібно враховувати при плануванні інноваційної діяльності.

12. Запити та побажання споживачів для підприємства індустрії гостинності є одним 3 найважливіших орієнтирів у прийнятті рішення щодо інновацій. Саме тому в процесі інноваційної діяльності суттєву роль відводять маркетингу як інструменту, який допомагає виявити існуючі потреби на етапі розробки інновацій, а також відстежувати відповідність існуючих інновацій запитам споживачів на етапі їхньої реалізації.

Наведений перелік особливостей сервісних інновацій для підприємства індустрії гостинності, безумовно, не є вичерпним; проте він може бути корисним для подальшого дослідження інновацій сфери послуг. Варто також врахувати, що частина наведених особливостей інноваційної діяльності не $є$ характерною для певних підприємств індустрії гостинносTi.

У вітчизняній літературі, незважаючи на наявність численних досліджень щодо відмінності сфери послуг від матеріального виробництва, практично відсутні публікації щодо специфіки інноваційної діяльності підприємств індустрії гостинності. Саме тому ми не можемо стверджувати, а лише припускаємо, засновуючись на вивченні наукових праць вітчизняних вчених, що вони тяжіють до асиміляційного (першого) підходу. Складена ситуація є результатом поданих ними класифікацій інновацій, які в основному складені за критеріями, виділеними раніше іншими вченими, що займаються питаннями матеріально- го виробництва (тобто використана методологія матеріального виробництва). Наслідком цього $є$ нова економіка, що зберегла атавізми матеріального виробництва ще з часів СРСР. Але з іншого боку, в сучасній економіці сфера послуг є провідним сектором, що активно розвивається та має істотні відмінності від матеріального. Проте важливим $є$ той факт, що саме матеріальне виробництво набуває ознак такого, яке надає все більше послуг. Матеріальна продукція випускається лише в купі із супутніми послугами. Іноді така «сервізація» проявляється шляхом просування товару за допомогою різноманітних послуг (страхування, тіхнічної підтримки, програмного забезпечення та інше). Важливо, що самі послуги стають більш техноємними, а їхнє виробництво набуває «індустріального» характеру. Часто можна спостерігати злиття матеріального виробництва і сфери послуг [17].

3 огляду на те, що багато промислових підприємств набувають сервісних характеристик, а виробництво ряду певних послуг все більше нагадує індустріальне, застосування в повній мірі асиміляційного або розмежувального підходів стає не зовсім коректним. Ряд авторитетних авторів (Ф. Галлудж, Р. Кумбс, І. Майлз) вважають, що доцільним в таких умовах буде реалізувати пошук синтезу, тобто поєднання цих двох протилежних підходів. Важливо, що запропонований синтетичний підхід має стати не чимось «середнім», навпаки, поєднати переваги кожного із своїх попередників. За допомогою синтетичного підходу стане можливим здійснення аналізу внутрішніх та зовнішніх відмінностей підприємст матеріального виробництва і сфери послуг (до якої відносять і підприємства індустрії гостинності). Цікаво, що для підприємства індустрії гостинності стане можливим застосування методології інновацій, яка існує в матеріальній сфері при іiї коригуванні, враховуючи особливості саме індустрії гостинності. Він також дозволить сформувати спільну платформу для розробки інтегральних програм підготовки кадрів, формування комплексної інноваційної політики і ін.

Висновки та перспективи подальших досліджень. Таким чином, можна зробити висновки, що індустрія гостинності - сектор сфери послуг, тісно пов'язаний $з$ індустрією туризму, яка об'єднує численні підприємства різної спрямованості, засновані на принципі гостинного обслуговування туристів, мандрівників, а також місцевого населення і організації їх відпочинку та дозвілля. На наш погляд, доцільно виділити наступні напрями розвитку інновацій підприємствами індустрії гостинності.

1. Техніко-технологічні параметри. Очевидно, сервісні інновації можливі і без технологічних нововведень, проте техніко-технологічні інновації часто є підтримуючими, що слугують основою для розробки і здійснення інших видів інновацій. Одним 3 найвпливовіших на виробничий процес в готельному бізнесі явищ став прогрес інноваційних технологій. Готельна діяльність за своїми специфічними особливостями є однією з перших, яка в повній мірі адаптувала до своїх потреб досягнення в сфері телекомунікацій і автоматизованих систем обробки інформації. 
Автоматизація дозволила готельним підприємствам збільшити ефективність діяльності за рахунок автоматизації і інтернет-систем, забезпечити максимальну присутність на споживчих ринках, максимально наблизившись до своїх потенційних клієнтів [3].

2. Сервісна концепція включає в себе сукупність всіх існуючих на підприємствах індустрії гостинності послуг. В процесі оцінки існуючої сервісної концепції на підприємстві проводиться бенчмаркінг, тобто порівняльний аналіз власних послуг і послуг інших підприємств; в результаті якого робиться висновок про необхідність вдосконалення існуючих або впровадження нових послуг. Наприклад, останнім часом широко впроваджується в готельному бізнесі використання оздоровчих центрів, СПА-послуг, ідея яких запозичена з косметологічної індустрії. Надання багатофункціональних послуг, зокрема обладнання готельних номерів модернізованими розважальними системами, є ще одним напрямом інноваційної діяльності готелів (залученого у індустрії розваг).

3. Система обслуговування (кліснтський інтерфейс) $є$ центральною ланкою інноваційної діяльності підприємств індустрії гостинності. 3 огляду на залучення споживачів до процесу надання послуг, а також клієнтоорієнтованого характеру діяльності підприємств індустрії гостинності стає можливим говорити про те, що споживачі послуг часто $є$ ініціаторами інновацій. Прикладом таких інновацій може бути можливість здійснення бронювання номерів готелю самим клієнтом через Інтернет, що дозволяє зауважи- ти, що клієнти грають все більшу роль в процесі виробництва самих послуг. У ресторанному бізнесі прикладом інновацій цього типу є створення закладів громадського харчування, в яких відвідувач сам (під наглядом кухаря) готує їжу, використовуючи заздалегідь заготовлені для цього інгредієнти.

Система обслуговування повинна бути «налаштована» на максимально просте і швидке вирішення будь-яких питань і запитів клієнтів. Наприклад, готельна мережа St. Regis пропонує своїм гостям нову послугу: бездротовий зв'язок з обслуговуючим персоналом. Особисті дворецькі в мережі зустрічають і проводжають гостей в аеропорту, замовляють столик в ресторані, крісло в театрі або зал для ділової зустрічі, допомагають розібрати або зібрати речі, стежать за виконанням всіх особливих побажань гостей і ін. [7, с. 20].

4. Концепція закладу в деяких випадках також може являти собою інновацію. Так, незвичайний формат закладів, дизайн, планування, а також нестандартний асортимент послуг дозволяють підприємству вигідно виділитися серед конкурентів. На наш погляд, зазначений напрям інноваційної діяльності становить особливий інтерес для керівників підприємствами індустрії гостинності, адже рівень конкурентоспроможності вітчизняних підприємств значно нижче закордонного; в той час як використання концептуальних інновацій дозволить створити унікальний стиль і залучити додаткових клієнтів.

\section{Література}

1. Шумпетер I. Теорія економічного розвитку. М .: Прогрес, 1982. 456 с.

2. Портер М. Міжнародна конкуренція. М.: Міжнародні відносини, 1993. 896 с.

3. Bright J. R. Some management lessons from technological innovation research: National conference on management technological innovation. Bradford: Univ. of Bradford Management Centre, 1968. $231 \mathrm{p}$.

4. Твисс Б. Управління науково-технічними нововведеннями. М.: Економіка, 1989. 271 с.

5. La technologie et l'economie: Les relation determinantes. R: OECD, 1992. p. 26.

6. Barras R. Towards a Theory of Innovation in Services. Research Policy. 1986. №15. P. 161-173. . doi: 10.1016/0048-7333(86)90012-0

7. Harzing A.W. (2019) Publish or Perish. Version 3.0.3883 (18 August). http://www.harzing.com/pop.htm. (дата звернення 18.07.20)

8. Майлс Й. Сервісні інновації в ХХІ столітті // Форсайт. 2011. №2. С. 4-15.

9. Седікова І. О. Управління інноваційною діяльністю підприємств кондитерської галуз // Науковий вісник Ужгородського національного університету. Сер. Міжнародні економічні відносини та світове господарство. 2018. Вип. 18. С. 55-59.

10. Bondarenko S., Lagodienko V., Sedikova I. \& Kalaman O. Application of Project Analysis Software in Project Management in the PreInvestment Phase. Journal of Mechanical Engineering and Technology. 2018. Vol.9, is.13, pp. 676-684.

11. Асауленко Н. В. Управління інноваціями в готельно-ресторанному бізнесу // Економічні та соціальні аспекти розвитку України на поч. 21 ст.: матеріали VI міжн. наук.-практ. конф., 2018 р. Одеса: «Студія "Печать», 2018. C. 11-13.

12. Sedikova I. Development of conceptual principles of the circular economy // Food Industry Economics. 2019. Vol.11, Issue 2. P. 47-53. doi: 10.15673/fie.v11i2.1394

13. Kalaman O., Volodina O., Mandrikin D. Innovative development strategy formation of the modern enterprise // Food Industry Economics. 2018. Vol.10 (2). P. 75-82. doi: 10.15673/fie.v10i2.963 


\author{
Асауленко Н.В. \\ аспирант \\ кафедра менеджмента и логистики \\ Одесская национальная академия пищевых технологий \\ ул. Канатная, 112, г. Одесса, Украина, 65039 \\ E-mail: Nataliya.asaulenko@ukr.net \\ ORCID: 0000-0001-7057-4614
}

\title{
ОСОБЕННОСТИ ИННОВАЦИОННОГО ПРОЦЕССА НА ПРЕДПРИЯТИЯХ ИНДУСТРИИ ГОСТЕПРИИМСТВА
}

В статье проведен анализ понятия инновационного процесса и инноваций, выяснена их сущность, начиная от первых упоминаний в научной литературе. Отмечено, что Й. Шумпетер, рассматривая аспекты новых изменений в развитии и представляя инновационный процесс, выделил типичные их изменения. Представлена проблематика инноваций в экономической теории и практике управления предприятиями. Показана необходимость избегать подхода, который базируется на идее простого обновления продукции и ограничивает поиск путей, объясняя как применить новую технику, и не всегда имеет максимальный коммерческий потенциал.

Представлены особенности инноваций в процессе реализации на предприятиях именно индустрии гостеприимства как одного из самых перспективных направлений развития экономики страны. Выделено главную их особенность - сервисный характер. Указана важность и целесообразность разделения инноваций на сервисные и производственные. Отмечено, что такая группировка именно с методологической точки зрения должна иметь первостепенное значение. Показано, что большая часть существующих инноваций ориентирована на фиксацию их отдельных видов на предприятиях материального производства. Для сервисных же предприятий многие из выделенных критериев классификации неприменимы, а иногда проявляют и совершенно противоположный характер. Показано, что понятие «сервисные инновации» означает инновации сферы услуг.

Выявлено, что ученые по своим взглядам на инновационные особенности сферы услуг разделяются на две группы: не разграничивающие сервисные и производственные инновации и абсолютно отличающие их друг от друга. Именно сторонники разграничительного подхода формируют специфический характер сервисных инноваций. Основным их утверждению является то, что исследования сервисных инноваций требует особого инструментария и новых теорий. Это позволило выделить особенности сервисных инноваций, применяемых предприятиями индустрии гостеприимства. Приведенный перечень особенностей сервисных инноваций для предприятия индустрии гостеприимства, безусловно, не является исчерпывающим; однако он может быть полезным для дальнейшего исследования инноваций сферы услуг. На основе проведенного исследования предложены направления развития инноваций предприятиями индустрии гостеприимства.

Ключевые слова: индустрия гостеприимства, инновация, инновационная деятельность, инновационный процесс, сервисные инновации, предприятия индустрии гостеприимства.

\author{
Asaulenko N. \\ Postgraduate student \\ Department of Management and Logistics \\ Odessa National Academy of Food Technologies \\ Kanatna str., 112 Odesa, Ukraine, 65039 \\ E-mail: Nataliya.asaulenko@ukr.net \\ ORCID: 0000-0001-7057-4614
}

\section{FEATURES OF THE INNOVATIVE PROCESS AT THE HOSPITALITY INDUSTRY ENTERPRISES}

The article analyzes the concept of innovation process and innovations, clarifies their essence, starting from the first references in the scientific literature. It has been noted that J.Schumpeter, considering the aspects of new changes in development and presenting the innovation process, identified their typical changes. The problems of innovations in the economic theory and practice of enterprise management have been presented. It shows the need to avoid an approach that is based on the idea of simple product renewal and limits the search for ways, explaining how to apply new techniques and does not always have the maximum commercial potential.

The features of innovations in the process of implementation at the enterprises of the hospitality industry as one of the most promising areas of development of the country's economy have been presented. 
Their main feature, - the service character, has been determined. The importance and expediency of dividing innovations into service and production have been indicated. It has been noted that such a grouping should be of paramount importance from a methodological point of view. It has been shown that most of the existing innovations are focused on fixing their individual types at the enterprises of material production. For service enterprises, many of the selected classification criteria are inapplicable, and sometimes show a completely opposite character. It has been shown that the concept of "service innovation" means innovation in the service sector.

It has been revealed that scientists in their views on the innovative features of the service sector are divided into two groups: those, who do not differentiate between service and those, who production innovations and absolutely distinguish them from each other. It is the proponents of the differentiating approach that form the specific character of service innovations. Their main claim is that the study of service innovations requires special tools and new theories. This made it possible to highlight the features of service innovations used by enterprises in the hospitality industry. The above list of features of service innovations for the hospitality industry enterprise is certainly not exhaustive; however, it may be useful for further research on service innovation. On the basis of the study, the directions for the development of innovations by enterprises of the hospitality industry have been proposed.

Key words: hospitality industry, innovation, innovative activity, innovative process, service innovations, hospitality industry enterprises.

\section{References}

1. Shumpeter, I. (1982). Teoriia ekonomichnoho rozvytku. Moscow: Prohres.

2. Porter, M. (1993). Mizhnarodna konkurentsiia. Moscow: Mizhnarodni vidnosyny.

3. Bright, J. R. (1968). Some management lessons from technological innovation research. National conference on management technological innovation. Bradford: Univ. of Bradford Management Centre.

4. Tvyss, B. (1989). Upravlinnia naukovo-tekhnichnymy novovvedenniamy. Moscow: Ekonomika.

5. La technologie et l'economie: Les relation determinantes (1992). R: OECD.

6. Barras, R. (1986). Towards a Theory of Innovation in Services. Research Policy, (15), 161-173. doi: 10.1016/0048-7333(86)90012-0

7. Harzing, A. W. (2019). Publish or Perish. Version 3.0.3883. Retrieved July 18, 2020, from http://www.harzing.com/pop.htm.

8. Mails, Y. (2011). Servisni innovatsii v XXI stolitti. Forsait, (2), 4-15.

9. Sedikova, I. O. (2018). Upravlinnia innovatsiinoiu diialnistiu pidpryiemstv kondyterskoi haluz. Naukovyi visnyk Uzhhorodskoho natsionalnoho universytetu, (18), 55-59.

10. Bondarenko, S., Lagodienko, V., Sedikova, I. \& Kalaman, O. (2018). Application of Project Analysis Software in Project Management in the PreInvestment Phase. Journal of Mechanical Engineering and Technology, 9(13), 676-684.

11. Asaulenko, N. V. (2018). Upravlinnia innovatsiiamy v hotelno-restorannomu biznesu. Ekonomichni ta sotsialni aspekty rozvytku Ukrainy na poch. 21 st., 11-13. Odesa: «Studiia "Pechat».

12. Sedikova, I. (2019). Development of conceptual principles of the circular economy. Food Industry Economics, 11(2), 47-53. doi: 10.15673/fie.v11i2.1394

13. Kalaman, O., Volodina, O., \& Mandrikin, D. (2018). Innovative development strategy formation of the modern enterprise. Food Industry Economics, 10(2), 75-82. doi: 10.15673/fie.v10i2.963

Received 3 August 2020

Approved 17 August 2020

Available in Internet 15.10.2020

Цитування згідно ДСТУ 8302:2015

Асауленко Н.В. Особливості інноваційного процесу на підприємствах індустрії гостинності // Економіка харчової промисловості. 2020. Т.12, вип. 3. С. 81-87. doi: 10.15673/fie.v12i3.1819

Cite as APA style citation

Asaulenko, N. (2020). Features of the innovative process at the hospitality industry enterprises. Food Industry Economics, 12(3), 81-87. doi: 10.15673/fie.v12i3.1819 